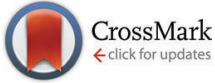

Cite this: Chem. Commun., 2016 52,124

Received 19th August 2015, Accepted 19th October 2015

DOI: $10.1039 / c 5 c c 06976 a$

www.rsc.org/chemcomm

\section{A two-photon fluorescent probe for lysosomal zinc ions $\dagger$}

\author{
Hyo-Jun Lee, $\ddagger^{\mathrm{a}}$ Chang-Woo Cho, ${ }^{\text {a }}$ Hyewon Seo, $\ddagger^{\mathrm{b}}$ Subhankar Singha, $\ddagger^{\mathrm{b}}$ \\ Yong Woong Jun, ${ }^{b}$ Kyung-Ha Lee, ${ }^{c}$ Youngseob Jung, ${ }^{c}$ Kyong-Tai Kim, ${ }^{c}$ \\ Seongjun Park, ${ }^{d}$ Sung Chul Bae ${ }^{d}$ and Kyo Han Ahn*b
}

The selective detection of zinc ions in lysosomes over that in cytosol is achieved with a fluorescent probe, which enabled the fluorescence imaging of endogenous zinc ions in lysosomes of NIH 3T3 cells as well as mouse hippocampal tissues by two-photon microscopy under excitation at $900 \mathrm{~nm}$.

Being the second most abundant transition metal ion in our body, $\mathrm{Zn}$ (II) is of paramount importance for maintaining biological functions including the modulation of biological redox systems, enzymatic functions, and cellular signalling. ${ }^{1}$ Imbalance in the intracellular $\mathrm{Zn}$ (II) level is associated with various diseases such as Alzheimer's disease, Parkinson's disease, diabetes, prostate cancer and immune dysfunction. ${ }^{2}$ The influence of $\mathrm{Zn}$ (II) on human health has motivated scientists to investigate " $\mathrm{Zn}$ (II) biology" by fluorescence methods. Accordingly, much efforts have been made to develop fluorescent $\mathrm{Zn}$ (II) probes for biological applications. A fluorescence assay based on the chelation of $\mathrm{Zn}$ (II) with $N$-(6-methoxy-8-quinolyl)-p-toluenesulfonamide was one of the earliest developments. ${ }^{3}$ Since then, significant progress has been made, and at present several fluorescent $\mathrm{Zn}$ (II) probes with high affinity, fast response, good biocompatibility, and preferably with longer excitation and emission wavelengths are available. ${ }^{4}$ Recently, the subcellular detection of Zn(II) by targeting a specific organelle has become a subject of great interest in this research field. For example, fluorescence imaging of zinc ions in a subcellular compartment such as mitochondria or lysosome has received considerable interests. ${ }^{5}$

\footnotetext{
${ }^{a}$ Department of Chemistry, Kyungpook National University, Daegu 702-701, Republic of Korea. E-mail: cwcho@knu.ac.kr

${ }^{b}$ Department of Chemistry, POSTECH, Pohang 790-784, Republic of Korea. E-mail:ahn@postech.ac.kr

${ }^{c}$ Division of Integrative Biosciences and Biotechnology, POSTECH, Pohang 790-784, Republic of Korea

${ }^{d}$ School of Life Sciences, UNIST, Ulsan 689-798, Republic of Korea

$\dagger$ Electronic supplementary information (ESI) available: Materials and procedures regarding the synthesis of the probe, one-photon and two-photon spectroscopic analysis, cell and tissue imaging experiments. See DOI: 10.1039/c5cc06976a

\$ Equally contributed.
}

In the biological systems, $\mathrm{Zn}$ (II)-bound metallothioneins are the main cytoplasmic proteins that maintain the intracellular $\mathrm{Zn}$ (II) homeostasis. During the oxidative stress, a rapid influx of hydrogen peroxide causes oxidation of the cysteine residues in $\mathrm{Zn}$ (II)-metallothioneins to disulfides and subsequent release of $\mathrm{Zn}$ (II) ions. ${ }^{6}$ The released $\mathrm{Zn}$ (II) ions are rapidly accumulated into the lysosomes, causing the lysosomal membrane permeabilization (LMP), a potentially lethal event. In this process, the additional $\mathrm{Zn}$ (II) ions in lysosomes induce lysosomal membrane disintegration and release several hydrolytic enzymes (including cathepsins) from the lysosomal lumen to the cytosol. The presence of lysosomal hydrolases in the cytosol causes the digestion of vital cytosolic proteins and the activation of additional hydrolases to initiate a cell death pathway. ${ }^{5 d, 7,8}$ Therefore, the development of fluorescent probes that selectively detect lysosomal $\mathrm{Zn}$ (II) ions, which act as a downstream marker for the LMP processes, is necessary to study the oxidative stress level. ${ }^{8}$

Among the many fluorescent $\mathrm{Zn}$ (II) probes developed so far, only a few are claimed to detect lysosomal $\mathrm{Zn}$ (II). ${ }^{9}$ Those probes have a lysosomal targeting moiety and thus accumulate in the lysosome to report Zn(II) ions there. Such probes thus rely on the "concentration gradient" of the probes between the cytosol and lysosomes; they hardly discriminate the $\mathrm{Zn}$ (II) ions in lysosomes from those in cytosol, as they show fluorescence response upon binding with $\mathrm{Zn}$ (II) in a broad $\mathrm{pH}$ range covering that of lysosomal pH (4.5-5.5) and cytosolic pH (7.2-7.4). Such concentration gradient-dependent probes report the probe's concentration gradient from the cytosol to lysosomes. Such probes also may present interference from non-specific imaging in the case of slow accumulation of the probe into lysosomes. On the contrary, a fluorescent probe that shows "quenched" fluorescence at cytosolic $\mathrm{pH}$ (7.4) even after binding with Zn(II) but strong fluorescence only at lysosomal $\mathrm{pH}(\mathrm{pH} 4.5-5.5)$ could provide highly specific lysosomal $\mathrm{Zn}$ (II) detection irrespective of the probe accumulation process.

Most of the existing $\mathrm{Zn}$ (II) probes are also one-photon excitable at short wavelengths outside the biological optical window. For tissue imaging applications, additional issues such as photobleaching of the probe and autofluorescence from tissues become serious 
concerns under one-photon excitation at the shorter wavelengths. The use of the low-energy near-infrared (NIR) excitation light under two-photon excitation conditions enables deeper tissue penetration and also alleviates the photobleaching and autofluorescence issues. ${ }^{10}$

Two-photon probes excitable at NIR wavelengths furthermore allow 3D imaging of tissues with very high spatial resolution. Accordingly, several two-photon $\mathrm{Zn}$ (II) probes have been developed, which showed turn-on ${ }^{11}$ or ratiometric fluorescence response. ${ }^{12}$ A few of them are also equipped with an organelle targeting function, which enabled the detection of the $\mathrm{Zn}$ (II) ions in the cellular membrane or mitochondria; but $\mathrm{Zn}$ (II) detection in the lysosomal site using two-photon microscopy (TPM) is rarely known. Recently a two-photon probe was reported that could detect endogenous $\mathrm{Zn}$ (II) ions in the $\mathrm{Zn}$ (II)-enriched acid vesicles such as insulin granules only; however, the imaging of the low level of endogenous lysosomal Zn(II) was not possible. ${ }^{13}$ Moreover, this twophoton probe also showed a similar level of response towards $\mathrm{Zn}$ (II) as well as Cd(II). Herein, we report a two-photon probe that allows selective detection of the endogenous $\mathrm{Zn}$ (II) ions in lysosomes, which also has an improved selectivity over Cd(II).

We designed probe $\mathbf{1}$ (Scheme 1) where a morpholine group and a $N, N$-di-(2-picolyl)ethylenediamine (DPEN) ligand are introduced into a naphthalimide dye. The naphthalimide dye is dipolar and has the maximum absorbance of around $450 \mathrm{~nm}$; hence, it would allow tissue imaging by TPM under excitation at $900 \mathrm{~nm}$, a wavelength at the longer side of the first biological optical window (650-950), which is beneficial in reducing autofluorescence observed in tissue imaging. ${ }^{14}$ Recently, we have disclosed a novel approach to make such a dipolar dye emit strongly in aqueous media, in particular under two-photon excitation conditions. ${ }^{15}$ Based on our findings and a previous example, ${ }^{16}$ we have chosen the naphthalimide dye for the development of the two-photon probe. It is known that a morpholine moiety is useful for the sensing purpose of lysosomal $\mathrm{pH}$, as a protonated morpholine has a $\mathrm{p} K_{\mathrm{a}}$ value of $\sim 5$, a lysosomal $\mathrm{pH}$. DPEN is known to bind metal ions such as $\mathrm{Zn}$ (II), $\mathrm{Cd}$ (II), and $\mathrm{Cu}$ (II). ${ }^{17}$ In this work, we have introduced the DPEN group to the naphthalimide dye in such a way that one of the imide carbonyl oxygen atoms could coordinate $\mathrm{Zn}$ (II) together with the DPEN nitrogen atoms, with a hope that this additional coordination would improve the metal ion selectivity as well as the binding affinity. Both are realized indeed.

Probe 1 thus designed can be readily synthesized from 4-bromo1,8-naphthalic anhydride (Scheme 2). Thus, the imide formation

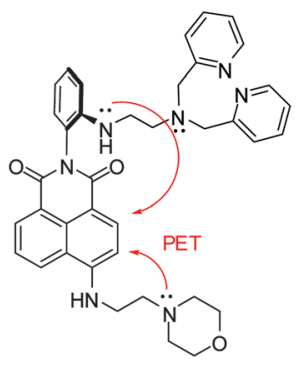

Probe 1 (non-fluorescent)

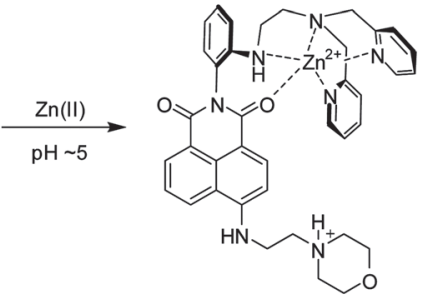

1-Zn(II) (highly fluorescent)
Scheme 1 Detection of zinc ions under acidic conditions with probe 1 through the blocking of two PET processes.

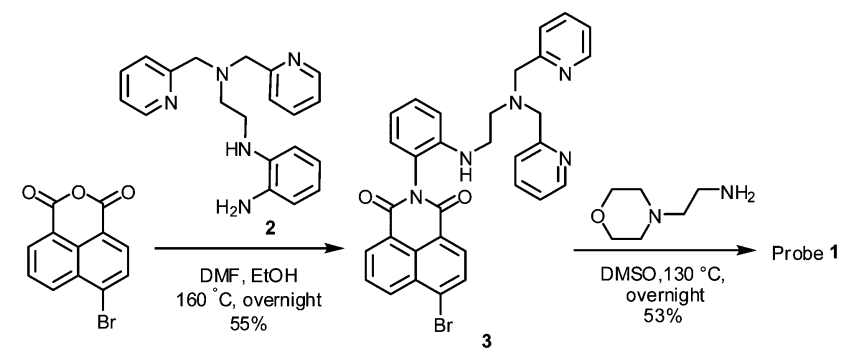

Scheme 2 Synthesis of probe 1

with DPEN containing amine precursor 2 and then electrophilic amine substitution at 4-position with 4-(2-aminoethyl)morpholine afforded probe $\mathbf{1}$ in a good yield (details are described in the ESI $\dagger$ ).

First we examined whether probe 1 could detect $\mathrm{Zn}$ (II) in the lysosomal $\mathrm{pH}$ range $(\mathrm{pH}=4.5-5.5)$. The fluorescence measurement at various $\mathrm{pH}$ values shows that probe $\mathbf{1}$ emits almost negligible fluorescence, whereas its $\mathrm{Zn}$ (II) complex emits strong fluorescence in the lysosomal $\mathrm{pH}$ range $(\mathrm{pH}=4.5-5.5)\left(\Phi_{\mathrm{F}}\right.$ of probe $1=0.03 ; \Phi_{\mathrm{F}}$ of $1-\mathrm{Zn}(\mathrm{II})=0.23$ in pH 5 buffer, Table S1 in the ESI $\dagger$ ); this is plausibly owing to the suppressed PET processes both from the Zn(II)coordinated DPEN site as well as from the protonated morpholine unit (Fig. 1a). The $K_{\mathrm{a}}$ values of probe 1 and its $\mathrm{Zn}$ (II) complex were 6.05 and 5.91, respectively, as determined from the fluorescence intensity changes within the $\mathrm{pH}$ range of 4.0-8.0 (Fig. S2 in the ESI $\dagger$ ).

The probe's emission intensity gradually increased with increasing $\mathrm{Zn}$ (II) concentration and finally saturated with an equivalent of $\mathrm{Zn}$ (II) ions at $\mathrm{pH}=5.0$ (Fig. $1 \mathrm{~b}$ and Fig. S3 in the ESI $\dagger$ ), indicative of $1: 1$ binding between the probe and $\mathrm{Zn}$ (II) in the acidic environment. The 1:1 binding stoichiometry was also observed at physiological pH of 7.4 (Fig. S4 in the ESI $\dagger$ ), albeit the final fluorescence intensity was much weaker $(\sim 1 / 6$ times) than that at $\mathrm{pH}=5.0$ (Fig. 1c). (a)

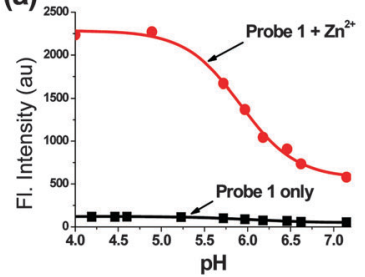

(c)

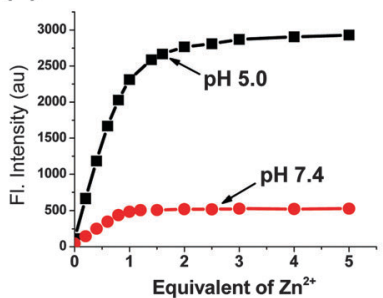

(b)

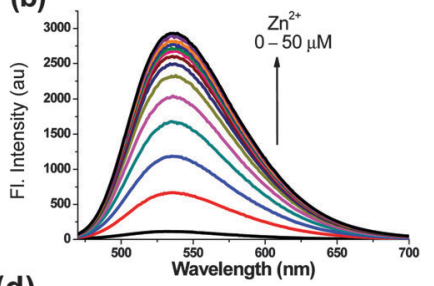

(d)

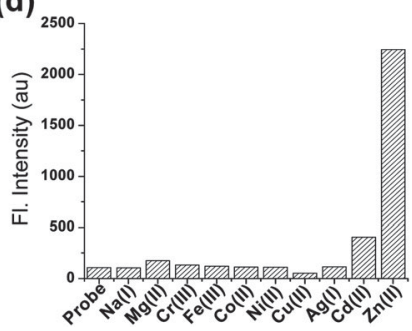

Fig. 1 (a) Fluorescence intensity changes of probe $1(10 \mu \mathrm{M})$ and its $\mathrm{Zn}(॥)$ complex under $\mathrm{pH}$ 4-7 MES buffer. (b) Fluorescence titration of probe 1 $(10 \mu \mathrm{M})$ with $\mathrm{Zn}\left(\mathrm{ClO}_{4}\right)_{2}$ in a pH 5.0 MES buffer containing $1 \% \mathrm{EtOH}$. (c) Fluorescence changes of probe $1(10 \mu \mathrm{M})$ in the presence of $\mathrm{Zn}(I)$ in a $20 \mathrm{mM} \mathrm{pH} 5.0$ MES buffer and in a $20 \mathrm{mM}$ pH 7.4 HEPES buffer, respectively. (d) Fluorescence intensity changes of probe $1(10 \mu \mathrm{M})$ with various metal ions $(10 \mu \mathrm{M})$ in $1 \% \mathrm{EtOH}$ containing a $\mathrm{pH} 5.0 \mathrm{MES}$ buffer. All the fluorescence data were obtained by excitation at $450 \mathrm{~nm}$. 
The lower fluorescence intensity of probe $\mathbf{1}$ in the presence of $\mathrm{Zn}$ (II) ions at neutral $\mathrm{pH}$ can be ascribed to the PET process from the morpholine to the naphthalimide dye. In fact, the behaviour of weak emission at cytosolic $\mathrm{pH}$ (7.4) and strong emission at lysosomal $\mathrm{pH}$ (4.5-5.5) is highly desirable for lysosomal $\mathrm{Zn}$ (II) imaging.

The previously reported lysosomal $\mathrm{Zn}$ (II) probes, ${ }^{9}$ after binding with $\mathrm{Zn}(\mathrm{II})$, showed strong fluorescence even at the cytosolic $\mathrm{pH}$ $(\mathrm{pH}=7.2-7.4)$; however, the accumulation of the probes into lysosomes provided enhanced fluorescence intensity in lysosomes compared to that in cytosol as noted above. On the contrary, our probe shows a low fluorescence intensity at cytosolic $\mathrm{pH}$ (7.4) even after binding with $\mathrm{Zn}$ (II) ions. A strong fluorescence intensity can be only observable when the probe binds $\mathrm{Zn}$ (II) ions inside the lysosomes ( $\mathrm{pH}$ 4.5-5.5).

Probe 1 showed a good linear response to [Zn(II)] even in the lower concentration region $(0-1.0 \mu \mathrm{M})$ at $\mathrm{pH}=5.0$ (Fig. S5 in the $\mathrm{ESI} \dagger$ ), offering a very high sensitivity toward $\mathrm{Zn}$ (II). The limit of detection was determined to be $0.18 \mu \mathrm{M}$ on the basis of the signalto-noise ratio of three (Fig. S6 in the ESI $\dagger$ ). The association constant $\left(K_{\mathrm{a}}\right)$ for probe 1 with $\mathrm{Zn}(\mathrm{II})$ was found to be $1.17 \times 10^{5} \mathrm{M}^{-1}$ (error $<$ $10 \%$ ), as determined from the Benesi-Hildebrand plot ${ }^{18}$ based on the fluorescence titration data. The high sensitivity and strong binding affinity of probe $\mathbf{1}$ towards $\mathrm{Zn}$ (II) indeed allowed us to detect the intracellular $\mathrm{Zn}$ (II) ions present in lysosomes where the free $\mathrm{Zn}$ (II) concentration is reached up to a micromolar level during certain stimulations, such as inflammation and oxidative stress. ${ }^{19}$

The high selectivity of $\mathrm{Zn}$ (II) over other common transition metals is also a key issue to be addressed in the development of a fluorescent probe. In comparison with the frequently used di(2picolyl)amine (DPA) receptors, the additional coordination site (one of the imide carbonyl groups) is found to not only improve the binding affinity to $\mathrm{Zn}$ (II) but also improve the selectivity over other competing metal ions. ${ }^{4 b, 9 b}$ Probe 1 thus showed high selectivity towards Zn(II) among various metal ions, in particular with a small interference from $\mathrm{Cd}(\mathrm{II})$, which is most interfering (Fig. 1d). Note that a related system with a para-substituted DPEN moiety showed a similar binding response towards $\mathrm{Zn}$ (II) as well as Cd(II). ${ }^{20}$ The competition assay revealed that probe 1 was also able to sense $\mathrm{Zn}$ (II) in presence of other metal ions, except $\mathrm{Cu}$ (II) and $\mathrm{Co}$ (II) that caused quenching due to their paramagnetic nature (Fig. S7 in the ESI $\dagger$ ). As the concentrations of these two metal ions are negligible in the human body (intracellular free copper is undetectable) compared to zinc ion, ${ }^{21}$ their interference is not a problematic issue during the detection and bioimaging of $\mathrm{Zn}$ (II).

Next we examined whether probe 1 could be used to detect intracellular $\mathrm{Zn}$ (II) ions in lysosomes by TPM. Prior to the bioimaging studies, a low level of cytotoxicity of probe 1 towards NIH 3T3 cells was confirmed by the MTT assay (Fig. S9 in the ESI $\dagger$ ). First, we evaluated the sensing capability of probe 1 in live NIH 3T3 cells in the absence and presence of an exogenous source of $\mathrm{Zn}$ (II) or a chelator that suppresses the intracellular Zn(II) level. The NIH 3T3 cells incubated with probe $\mathbf{1}$ for $30 \mathrm{~min}$ showed strong fluorescence when observed by TPM, apparently from the intracellular Zn(II) ions (Fig. 2a). When the probe-treated cells were again incubated for 10 min with an exogenous $\mathrm{Zn}$ (II) source $\left(1: 1\right.$ mixture of $\mathrm{Zn}\left(\mathrm{ClO}_{4}\right)_{2}$ and pyrithion, which in situ forms the $\mathrm{Zn}$-pyrithion complex that

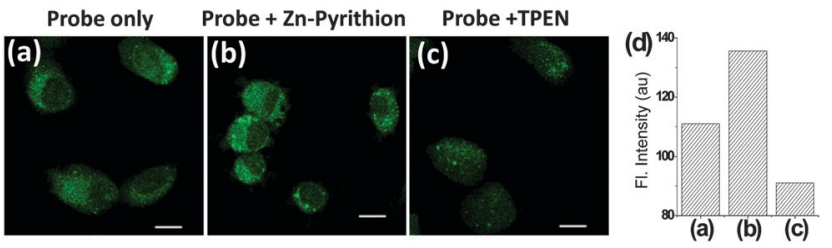

Fig. 2 TPM imaging of $\mathrm{Zn}(\mathrm{II})$ ions in live NIH 3T3 cells: (a) the cells were incubated with probe $1(30 \mu \mathrm{M})$ for $30 \mathrm{~min}$; (b) the cells were incubated with probe $1(30 \mu \mathrm{M})$ for $30 \mathrm{~min}$, followed by further incubation with a mixture of $60 \mu \mathrm{M}$ of $\mathrm{Zn}\left(\mathrm{ClO}_{4}\right)_{2}$ and pyrithione (1:1 mixture) for $10 \mathrm{~min}$; (c) the cells were incubated with probe $1(30 \mu \mathrm{M})$ for $30 \mathrm{~min}$, followed by further incubation with TPEN $(150 \mu \mathrm{M})$ for $10 \mathrm{~min}$. The images were obtained under excitation at $900 \mathrm{~nm}$ with a $3 \mathrm{~mW}$ input laser power at the focal plane. Scale bar: $10 \mu \mathrm{m}$. (d) Relative intensity plot of the respective TPM images shown in (a)-(c), obtained by collecting and averaging of all the data pixels.

enhances the cell-membrane permeability ${ }^{22}$ ), there was a substantial increase in the fluorescence intensity in the cells (Fig. 2b). In contrast, the fluorescence signal decreased significantly when the probe-treated cells were incubated with $N, N, N^{\prime}, N^{\prime}$-tetrakis(2pyridylmethyl)ethylenediamine (TPEN), for $10 \mathrm{~min}$ (Fig. 2c).

TPEN is a strong chelator for Zn(II) ions, which inhibits the binding of zinc ions by the probe. The relative fluorescence intensity data of the respective images show the fluorescence changes dependent on the Zn(II) ions (Fig. 2d). From the above set of experiments, it is evident that probe 1 allows us to detect and image the lysosomal $\mathrm{Zn}$ (II) ions by using TPM. Similar results were also obtained when the cells were observed by using a one-photon confocal microscope (Fig. S10 in the ESI $\dagger$ ).

To ensure that probe 1 can sense the $\mathrm{Zn}$ (II) ions in lysosomes, we performed a co-localization experiment with a commercial marker for lysosomes (LysoTracker ${ }^{\circledR}$ Deep Red) in live NIH 3T3 cells. The TPM images obtained through different optical windows clearly show well merging (Fig. 3a-c). Additionally, the intensity profiles of the two linear regions of interest (ROI 1 and ROI 2) across the cells also vary in close synchronicity (Fig. 3d and e). The Pearson's

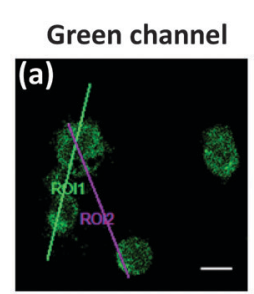

(d)

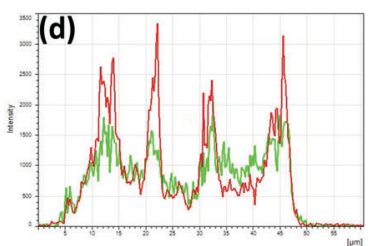

Red channel
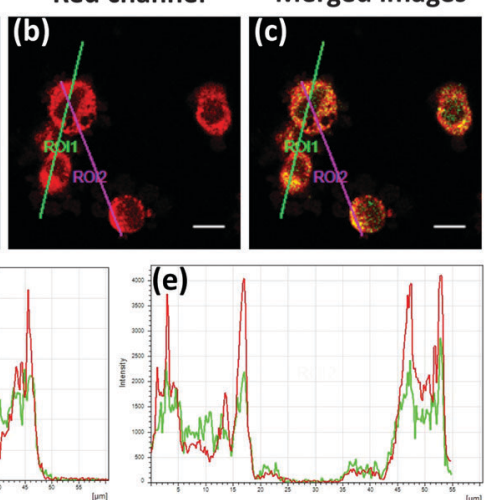

Fig. 3 Pseudo-colored fluorescence images of NIH 3 T3 cells: (a) TPM images of cells co-incubated with probe $1(30 \mu \mathrm{M})$ followed by $\mathrm{Zn}\left(\mathrm{ClO}_{4}\right)_{2}$ and pyrithione $(1: 1)$ solution $(60 \mu \mathrm{M})$, collected in the green channel window $(500-630 \mathrm{~nm})$ under excitation at $900 \mathrm{~nm}$. (b) OPM images of cells incubated with LysoTracker Deep Red $(1 \mu \mathrm{M})$ for $10 \mathrm{~min}$ at $37{ }^{\circ} \mathrm{C}$, collected in the red channel window $(670-750 \mathrm{~nm})$ under excitation at $633 \mathrm{~nm}$. (c) Merged images. Scale bar: $10 \mu \mathrm{m}$. (d and e) Intensity profiles measured across the NIH 3T3 cells: (d) ROI 1 and (e) ROI 2. 

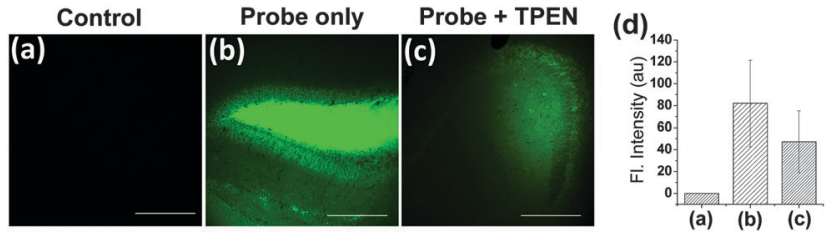

Fig. 4 Two-photon microscopic imaging of $\mathrm{Zn}(\mathrm{II})$ in mouse brain (hippocampus) tissues. (a) The tissue without probe treatment; (b) the tissue was incubated with probe $1(10 \mu \mathrm{M})$ for $30 \mathrm{~min}$; (c) the tissue was incubated with probe $1(10 \mu \mathrm{M})$ for $30 \mathrm{~min}$, followed by further incubation with TPEN $(150 \mu \mathrm{M})$ for $10 \mathrm{~min}$. Two-photon images were obtained under excitation at $900 \mathrm{~nm}$ with a $22.5 \mathrm{~mW}$ laser power at the depth of $150 \mu \mathrm{m}$ inside the tissue samples. Scale bar: $250 \mu \mathrm{m}$. (d) Relative intensity plot of the respective TPM images shown in (a)-(c).

co-localization coefficient, which describes the correlation of the intensity distributions to characterize the degree of overlap between images, was calculated to be 0.87 by using the LAS AF software (Table S2 in the ESI $\dagger$ ). Also, the co-localization experiments performed using commercial dyes showed that the probe poorly localizes in the mitochondria and the endoplasmic reticulum (Fig. S11 and $\mathrm{S} 12$ in the ESI $\dagger$ ). Hence, all the above data support that probe 1 detects intracellular lysosomal $\mathrm{Zn}$ (II) ions with a high fidelity.

With the two-photon excitable probe 1, we also imaged $\mathrm{Zn}$ (II) ions in deep tissues of a mouse brain (hippocampal slice). The TPM images of the tissue slice incubated with probe 1 show strong fluorescence apparently due to endogenous free $\mathrm{Zn}$ (II) in the mouse brain, ${ }^{1 b, 2 a}$ whereas the tissue without probe treatment (used as the control) does not show any fluorescence (Fig. 4). Again, the addition of a metal chelator TPEN to the probe-treated tissue reduces the fluorescence intensity. These imaging experiments altogether demonstrate the potential applicability of probe 1 for the imaging of endogenous Zn(II) ions in tissues by TPM.

In conclusion, we have developed a novel two-photon probe that selectively detects the $\mathrm{Zn}$ (II) ions in lysosomes over those in cytosol. The probe, a naphthalimide dye composed of an $\mathrm{N}, \mathrm{N}$-di-(2picolyl)ethylenediamine (DPEN) ligand and a morpholine unit, only fluoresces in the presence of $\mathrm{Zn}$ (II) ions at the lysosomal $\mathrm{pH}$, with high sensitivity as well as improved selectivity over the most competing $\mathrm{Cd}(\mathrm{II})$ ions. The probe enabled the fluorescence imaging of a lower level of intracellular $\mathrm{Zn}$ (II) ions present in lysosomes as well as in mouse brain tissues under two-photon excitation conditions at $900 \mathrm{~nm}$. The probe thus provides a useful tool for investigating various biological processes associated with lysosomal $\mathrm{Zn}$ (II) ions by two-photon microscopy.

K. H. Ahn thanks the financial supports from the Ministry of Health \& Welfare (HI13C1378) and Global Research Laboratory Program (2014K1A1A2064569) through the National Research Foundation (NRF) funded by Ministry of Science, ICT \& Future Planning. C. W. Cho thanks the financial support from the Kyungpook National University Research Fund, 2014.

\section{Notes and references}

1 (a) C. J. Frederickson, Int. Rev. Neurobiol., 1989, 31, 145; (b) A. S. Nakashima and R. H. Dyck, Brain Res. Rev., 2009, 59, 347.

2 (a) C. J. Frederickson, J. Y. Koh and A. I. Bush, Nat. Rev. Neurosci., 2005, 6, 449; (b) S. A. Parasad, Annu. Rev. Nutr., 1985, 5, 341; (c) S. K. Ghosh,
P. Kim, X. A. Zhang, S. H. Yun, A. Moore, S. J. Lippard and Z. Medarova, Cancer Res., 2010, 70, 6119.

3 C. J. Frederickson, E. J. Kasarskis, D. Ringo and R. E. Frederickson, J. Neurosci. Methods, 1987, $20,91$.

4 (a) K. P. Carter, A. M. Young and A. E. Palmer, Chem. Rev., 2014, 114, 4564; (b) Z. Xu, J. Yoon and D. R. Spring, Chem. Soc. Rev., 2010, 39, 1996; (c) E. M. Nolan and S. J. Lippard, Acc. Chem. Res., 2009, 42, 193; (d) E. L. Que, D. W. Domaille and C. J. Chang, Chem. Rev., 2008, 108, 1517; (e) Y. Chen, Y. Bai, Z. Han, W. He and Z. Guo, Chem. Soc. Rev., 2015, 44, 4517.

5 (a) S. L. Sensi, H. Z. Yin and J. H. Weiss, Eur. J. Neurosci., 2000, 12, 3813; (b) S. L. Sensi, D. Ton-That, P. G. Sullivan, E. A. Jonas, K. R. Gee, L. K. Kaczmarek and J. H. Weiss, Proc. Natl. Acad. Sci. U. S. A., 2003, 100, 6157; (c) J. P. Luzio, P. R. Pryor and N. A. Bright, Nat. Rev. Mol. Cell Biol., 2007, 8, 622; (d) J. J. Hwang, S.-J. Lee, T.-Y. Kim, J.-H. Cho and J.-Y. Koh, J. Neurosci., 2008, 28, 3114 .

6 (a) A. Krężel and W. Maret, JBIC, J. Biol. Inorg. Chem., 2008, 13, 401; (b) R. A. Colvin, W. R. Holmes, C. P. Fontaine and W. Maret, Metallomics, 2010, 2, 306; (c) S. G. Bell and B. L. Vallee, ChemBioChem, 2009, 10, 55.

7 (a) S.-J. Lee and J.-Y. Koh, Mol. Brain, 2010, 3, 30; (b) S. L. Sensi, P. Paoletti, J.-Y. Koh, E. Aizenman, A. I. Bush and M. Hershfinkel, J. Neurosci., 2011, 31, 16076; (c) P. Boya and G. Kroemer, Oncogene, $2008,27,6434$.

8 H. C. Roh, S. Collier, J. Guthrie, J. D. Robertson and K. Kornfeld, Cell Metab., 2012, 15, 88.

9 (a) L. Xue, G. Li, D. Zhu, Q. Liu and H. Jiang, Inorg. Chem., 2012, 51, 10842; (b) H. Zhu, J. Fan, S. Zhang, J. Cao, K. Song, D. Ge, H. Dong, J. Wang and X. Peng, Biomater. Sci., 2014, 2, 89; (c) K. Sreenath, Z. Yuan, J. R. Allen, M. W. Davidson and L. Zhu, Chem. - Eur. J., 2014, 20, 867.

10 W. R. Zipfel, R. M. Williams and W. W. Webb, Nat. Biotechnol., 2003, 2, 1369.

11 (a) H. M. Kim, M. S. Seo, M. J. An, J. H. Hong, Y. S. Tian, J. H. Choi, O. Kwon, K. J. Lee and B. R. Cho, Angew. Chem., Int. Ed., 2008, 47, 5167; (b) G. Masanta, C. S. Lim, H. J. Kim, J. H. Han, H. M. Kim and B. R. Cho, J. Am. Chem. Soc., 2011, 133, 5698; (c) Z. Mao, L. Hu, X. Dong, C. Zhong, B.-F. Liu and Z. Liu, Anal. Chem., 2014, 86, 6548; (d) C. Huang, J. Qu, J. Qi, M. Yan and G. Xu, Org. Lett., 2011, 13, 1462; (e) X.-Y. Chen, J. Shi, Y.-M. Li, F.-L. Wang, X. Wu, Q.-X. Guo and L. Liu, Org. Lett., 2009, 11, 4426; $(f)$ M. Khan, C. R. Goldsmith, Z. Huang, J. Georgiou, T. T. Luyben, J. C. Roder, S. J. Lippard and K. Okamoto, Proc. Natl. Acad. Sci. U. S. A., 2014, 111, 6786.

12 (a) M. Taki, J. L. Wolford and T. V. O'Halloran, J. Am. Chem. Soc., 2004, 126, 712; (b) X. Meng, S. Wang, Y. Li, M. Zhu and Q. Guo, Chem. Commun., 2012, 48, 4196; (c) K. P. Divya, S. Sreejith, P. Ashokkumar, K. Yuzhan, Q. Peng, S. K. Maji, Y. Tong, H. Yu, Y. Zhao, P. Ramamurthy and A. Ajayaghosh, Chem. Sci., 2014, $5,3469$.

13 P. Rivera-Fuentes, A. T. Wrobel, M. L. Zastrow, M. Khan, J. Georgiou, T. T. Luyben, J. C. Roder, K. Okamoto and S. J. Lippard, Chem. Sci., 2015, 6, 1944.

14 D. Kim, H. Moon, S. H. Baik, S. Singha, Y. W. Jun, T. Wang, K. H. Kim, B. S. Park, J. Jung, I. Mook-Jung and K. H. Ahn, J. Am. Chem. Soc., 2015, 137, 6781.

15 S. Singha, D. Kim, B. Roy, S. Sambasivan, H. Moon, A. S. Rao, J. Y. Kim, T. Joo, J. W. Park, Y. M. Rhee, T. Wang, K. H. Kim, Y. H. Shin, J. Jung and K. H. Ahn, Chem. Sci., 2015, 6, 4335.

16 H. Yu, Y. Xiao and L. Jin, J. Am. Chem. Soc., 2012, 134, 17486.

17 E. Kawabata, K. Kikuchi, Y. Urano, H. Kojima, A. Odani and T. Nagano, J. Am. Chem. Soc., 2005, 127, 818.

18 H. A. Benesi and J. H. Hildebrand, J. Am. Chem. Soc., 1949, 71, 2703.

19 (a) Y. Li, C. J. Hough, S. W. Suh, J. M. Sarvey and C. J. Frederickson, J. Neurophysiol., 2001, 86, 2597; (b) T. E. Kehl-Fie and E. P. Skaar, Curr. Opin. Chem. Biol., 2010, 14, 218.

20 J. Wang, Y. Xiao, Z. Zhang, X. Qian, Y. Yanga and Q. Xu, J. Mater. Chem., 2005, 15, 2836.

21 (a) T. D. Rae, P. J. Schmidt, R. A. Pufahl, V. C. Culotta and T. V. O'Halloran, Science, 1999, 284, 805; (b) P. Kajič, I. Milošev, B. Pihlar and V. Pišot, J. Trace Elem. Med. Biol., 2003, 17, 153.

22 C. J. Chang, J. Jaworski, E. M. Nolan, M. Sheng and S. J. Lippard, Proc. Natl. Acad. Sci. U. S. A., 2004, 101, 1129. 